\title{
Antioxidant and anti-apoptotic effects of selenium nanoparticles against murine eimeriosis
}

\author{
ABDULSALAM ALKHUDHAYRI, ESAM M. AL-SHAEBI, MAHMOOD A.A. QASEM, \\ MUTEE MURSHED, MOHAMMED M. MARES, SALEH AL-QURAISHY \& \\ MOHAMED A. DKHIL
}

\begin{abstract}
Eimeriosis is caused by a protozoan parasite of the genus Eimeria and infection affecting most domestic animal species. The aim of this research was to comprehend the impact of selenium nanoparticles (SeNPS) on eimeriosis induced by Eimeria papillata in mouse jejunum, and how they work as antioxidants and antiapoptotic agents against eimeriosis. The numbers of meronts, gamonts, and developing oocysts of E. papillata reduced after the infected mice were treated with the SeNPs. The levels of malondialdehyde (MDA), nitric oxide (NO), and other oxidative stress-related molecules, such as glutathione (GSH), catalase (CAT), and superoxide dismutase (SOD), were assayed. E. papillata was able to change the redox status of the jejunal cells; this was confirmed by the elevation of the MDA and NO levels, and the decrease of the GSH levels and the activities of the antioxidant enzymes CAT and SOD. SeNP treatment significantly reversed this disturbance of the redox status. The expression levels of the apoptotic markers Bax and caspase- 3 in the jejunal samples were evaluated using qRTPCR. The SeNPs decreased the Bax and caspase-3 expression after being administered to the E. papillata-infected mice. Collectively, the SeNPs demonstrated antioxidant and anti-apoptotic activities against murine eimeriosis.
\end{abstract}

Key words: selenium nanoparticles, eimeriosis, oxidative stress, apoptosis, mice.

\section{INTRODUCTION}

Eimeriosis is one of the most dangerous poultry diseases around the world (Ola-Fadunsin \& Ademola 2013). This parasitic disease, which is caused by coccidian parasites belonging to the genus Eimeria, induces problems for the poultry industry (Lawal et al. 2016). Reduced weight, diarrhea, and dehydration are the common clinical signs after the infection (Mehlhorn 2014). This disease has led to a global annual loss of about \$3 billion USD for the poultry industry (Blake \& Tomley 2014).
Due to the increased side effects of the currently used drugs against eimeriosis (e.g. Sulfaquinoxaline, Nitrofurazone, Nicarbazin, Amprolium) (Mehlhorn 2014), finding alternative agents such as natural products for the protection of poultry and fighting this parasite is of urgent need. Recently, nanoparticles have been considered to be innovative antiparasitic agents; particles of various elements contain different properties at the nano-size and at the micro-size. For example, Alkhudhayri et al. (2018) reported that nano-selenium (NS) is more effective against eimeriosis than elemental selenium. Moreover, NS is a highly bioavailable 
agent with low toxicity (Hu et al. 2012, Gangadoo et al. 2018).

During eimeriosis, there was an imbalance in the antioxidant status, where free radicals were highly produced (Dkhil et al. 2013). Additionally, the parasite stimulates the formation of reactive oxygen species, to induce injuries to the intestinal epithelium, resulting in an overload of free radicals and oxidative stress (Georgieva et al. 2006). Several studies confirmed that NS could efficiently produce favorable antioxidant effects (Bai et al. 2017). In addition, Alkhudhayri et al. (2018) reported that selenium nanoparticles (SeNPS) are considered to be efficient antioxidants.

Our previous work demonstrated the antiinflammatory effects of NS against E. papillata infection. These effects occurred via the downregulation of the gene expression of proinflammatory cytokines (Alkhudhayri et al. 2018). This is the first study to our understanding that examines the impacts of SeNPs on eimeriosis induced apoptosis. The efficient dose of the SeNPs used in this research was the same as the dose used in our prior research $(0.5 \mathrm{mg} /$ $\mathrm{kg})$; thus, we investigated the role of SeNPs against apoptotic changes in mouse jejunum and the oxidative damage caused by E. papillata infection.

\section{MATERIALS AND METHODS}

\section{Characterization of SeNPs}

NS with a particle size of about 5-50 nm was purchased from the Nanocs Inc (Boston, MA, USA). The nanoparticles were re-dispersed in aqueous medium by sonication. Transmission electron microscopy (TEM) was performed using a JEOL JEM-2100 microscope (JEOL Ltd., Tokyo, Japan) with an accelerating voltage of $200 \mathrm{kV}$ to characterize the shape and size of SeNPs (Jiang et al. 2008). The composition or finger print of the NS was characterized by Fourier Transform Infrared (FTIR) spectroscopy in the range of 4000-400 $\mathrm{cm}^{-1}$.

\section{Animals}

Thirty adult male C57BL/6 mice (20-23 g, 1012 weeks old) were obtained from the animal housing facilities at the King Saud University. A normal diet and water ad libitum were fed to the mice. All animal procedures and tests in this research have been endorsed by the committee of the Department of Zoology, King Saud University (Number: DGS 1438/6/20) and performed in accordance with animal experimentation rules.

\section{Infection and treatment}

To prepare the parasite culture (sporulated Eimeria papillata oocysts) for the infection of the mice, unsporulated oocysts were collected from mice feces and allowed to sporulate in $2.5 \%(\mathrm{w} / \mathrm{v})$ potassium dichromate, counted, and then expressed as the number of oocysts per gram of feces (Schito et al. 1996).

The animals were divided into three groups (10 mice per group): non-infected control group, comprising mice that orally gavaged with $100 \mu \mathrm{l}$ of phosphate buffer, infected group, comprising mice infected with 1000 sporulated oocysts of E. papillata, and the infected-treated group, in which after being infected with 1000 oocysts, the mice were daily inoculated with $0.5 \mathrm{mg} / \mathrm{kg}$ SeNPs for 5 days. The dose was chosen depending on our previous work (Alkhudhayri et al. 2018). All animals were killed by dislocation of the cervix.

\section{Sample collection}

On day 5 post-infection (p.i.), fresh feces were collected from the mice and the oocyst output per gram of feces was calculated (Esch \& Petersen 2013). Additionally, the suppression of oocyst shedding was calculated as follows: 
100 - (oocysts output in treated group/oocysts output in the infected group) $\times 100$.

\section{Parasitic stages}

To evaluate the number of E. papillata cells from different parasitic stages in the mouse jejunum samples, fresh jejuna were collected after the dissection of the mice on day 5 p.i. and fixed in $10 \%$ buffered formalin. Paraffin sections were prepared and stained with eosin and hematoxylin (Adam \& Caihak 1964). Under the light microscope, the number of meronts, gamonts, and developing oocysts per 10 cryptvillus units were counted.

\section{Oxidative stress markers and antioxidant enzymes}

A part of the jejunal samples was homogenized immediately, to prepare a 10\% (w/v) homogenate in ice-cold medium containing $50 \mathrm{mM}$ Tris- $\mathrm{HCl}$ and 300 mM sucrose (Tsakiris et al. 2004). For 10 min, the homogenate was centrifuged at $1500 \mathrm{~g}$. For the different biochemical determinations, the supernatant (10 percent) was used. Ellman's (1959) method has been used to determine glutathione (GSH). Lipid peroxidation was determined using the method described by Ohkawa et al. (1979). The nitric oxide (NO) level was measured by the determination of the total nitrate and nitrite concentrations in the samples using the method described by Berkels et al. (2004). Catalase (CAT) and superoxide dismutase (SOD) activities were assayed according to the protocols described by Aebi (1984) and Nishikimi et al. (1972), respectively.

\section{Apoptotic changes}

To examine the apoptotic changes induced by E. papillata infection, the mRNA expression of Bcl-2-associated $X$ protein (Bax) and cysteineaspartic acid protease-3 (Caspase-3) was assayed using quantitative real-time polymerase chain reaction (RT-PCR). Using Trizol (Thermo Fisher Scientific, Waltham, MA, USA), total RNA was isolated from the jejunal samples of the mice. QuantiTect ${ }^{\circledR}$ Reverse Transcription kit (Qiagen, Hilden, Germany) was used to generate the cDNA. RT-PCR was performed using the QuantiTectTM SYBR ${ }^{\circledR}$ Green PCR kit (Qiagen). The $2^{-\Delta \Delta C t}$ method described by Livak \& Schmittgen (2001) was used to evaluate the differences between the mean expression levels of the apoptotic genes and the reference gene glyceraldehyde-3phosphate dehydrogenase (GAPDH) (Livak \& Schmittgen 2001). The following primers, which were purchased from Qiagen (Hilden, Germany), were used: CASP3 (Mm_Casp3_1_SG, QT00260169), BAX (Mm_Bax_1_SG, Cat. No. QT00102536), and GAPDH (Mm_Gapdh_3_SG, Cat. No. QT01658692) (Krücken et al. 2009).

\section{Statistical analysis}

ANOVA analysis was performed in one way and statistical comparisons between groups were performed using Duncan's test. Values were expressed as the mean \pm SD, at a significance level of $p \leq 0.05$

\section{RESULTS}

To evaluate the detailed morphology of the nanoparticles, the samples were analyzed using TEM. The morphology of the SeNPs is presented in Figure 1a. The image shows that the NPs are very small and fine, with a clear spherical and cubic-shaped morphology. The size of each nanoparticle is about $20 \mathrm{~nm}$, with a spherical shape. Figure 1b shows the high-magnification TEM image of the NPs; the lattice distance between two fringes is $\sim 0.235$ $\mathrm{nm}$, which corresponds to the lattice constant of the SeNPs. Additionally, FTIR spectroscopy 

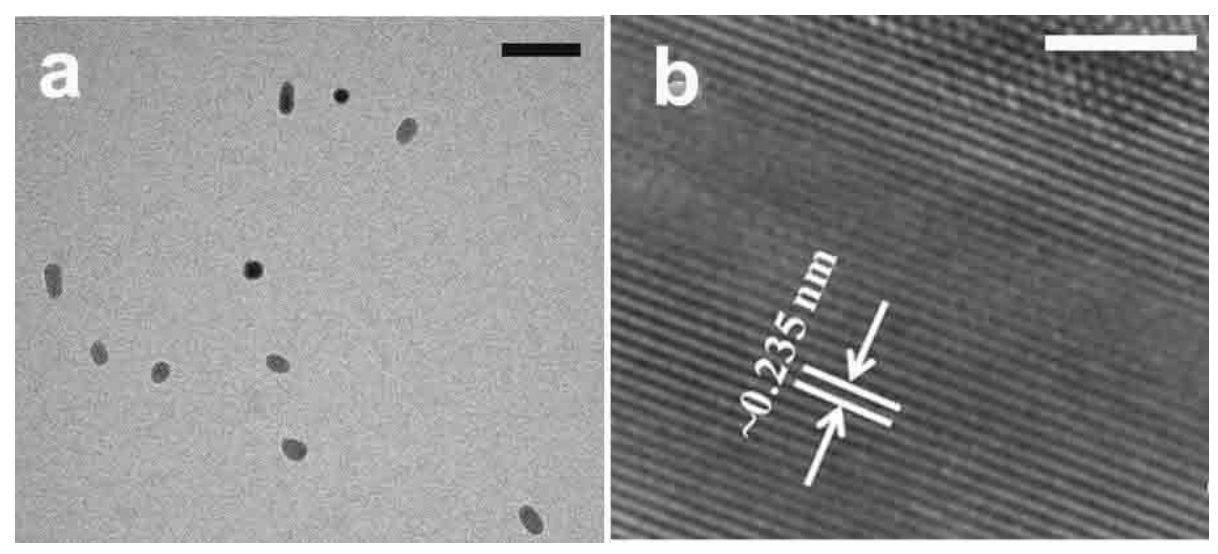

Figure 1. Characterization of selenium nanoparticles (a) Low-magnification TEM image of the selenium nanoparticles. Scale bar = $100 \mathrm{~nm}$. (b) The corresponding highresolution transmission electron microscopy (HR-TEM) image of (a) denoting the fringe distance, which is about $\sim 0.235 \mathrm{~nm}$. Scale bar $=2$ $\mathrm{nm}$.

was utilized to identify the functional groups present in aqueous SeNPs (Figure 2). For the analysis of FTIR measurement, the liquid sample comprising the SeNPs was drop casted onto the $\mathrm{KBr}$ plate and fixed to the holder. The FTIR spectrum shows the representative asymmetric and symmetric stretching vibration bands of the SeNPs. A broad peak was observed in the range of $3200-3500 \mathrm{~cm}^{-1}$, which is closely related to the amide $(-\mathrm{N}-\mathrm{H})$ group, whereas the peak at 1635 $\mathrm{cm}^{-1}$ represents the $\mathrm{C}=0$ group (Kalishwaralal et al. 2014). The peak at $791 \mathrm{~cm}^{-1}$ corresponds to the stretching mode of the metal peaks of selenium.

Jejunal sections from mice infected with $E$. papillata on day 5 p.i. (Figure 3) showed different the developmental stages of the parasite, i.e. meronts, gamonts and developing oocysts. The number of meronts, gamonts, and developing oocysts of the parasite decreased from $14.2 \pm 0.7$, $22 \pm 0.9,30.2 \pm 1.2$ in the mice from the infected group to $10.2 \pm 0.1,11 \pm 0.3,10.6 \pm 0.2$ in those from the infected-treated group, respectively (Table I). The SeNPs were able to suppress the proportion of meronts, gamonts, and developing oocysts by 28.2, 50, and 64.7\%, respectively (Table I).

To investigate the antioxidant effects of the SeNPs, the GSH, malondialdehyde, NO, CAT, and SOD levels were examined (Table II). Compared to the non-infected control group, the infected jejunal level of GSH $(0.422 \pm 0.05)$,

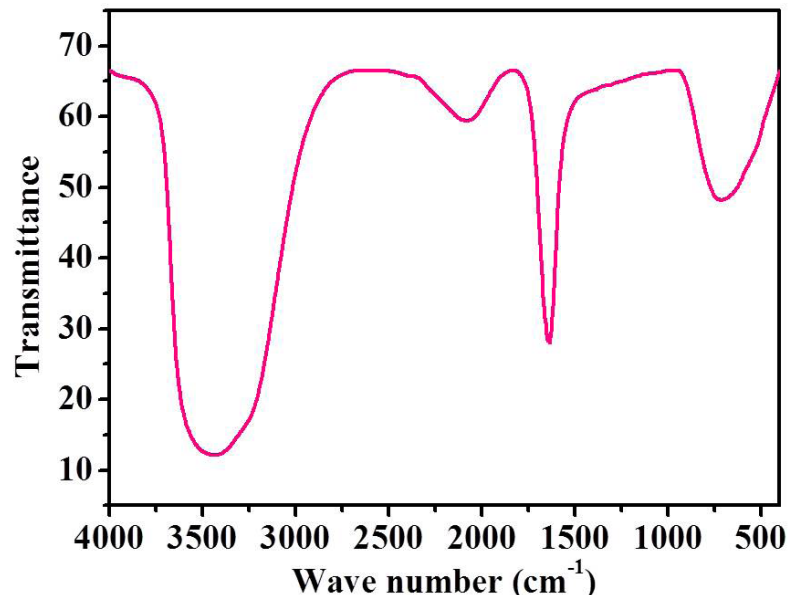

Figure 2. Fourier Transform Infrared spectroscopy (FTIR) of selenium nanoparticles in an aqueous medium showing the functional characteristics of the nanoparticles.

malondialdehyde $(97.32 \pm 7.76)$ and NO $(1.74 \pm 0.21)$ were changed. Also, the same for the activity of CAT $(43.78 \pm 5.95)$ and SOD $(11.5 \pm 2.44)$, they were significantly decreased.

The disturbances in the levels of these markers due to E. papillata infection were significantly ameliorated, and the oxidative stress in the jejunum was inhibited after the treatment with the SeNPs.

There was a significant change in the expression of apoptotic genes after the treatment of infected mice with the SeNPs. E. papillata infection induced the upregulation of the gene 



Figure 3. Jejunum sample infected with E. papillata on day 5 p.i. with different developmental stages of E. papillata: macrogamont (white arrow), microgamont (black arrow), developing oocyst (white arrow head), and meront (arrow head). The sections were stained with hematoxylin and eosin. Scale bar $=25 \mu \mathrm{m}$.

Table I. Effect of SeNPs on Eimeria papillata developmental stages in jejunum of mice per ten villus-crypt units on day 5 p.i.

\begin{tabular}{|c|c|c|c|}
\hline Parasitic stages & Infected & Infected-treated & Suppression (\%) \\
\hline Meronts & $14.2 \pm 0.7$ & $10.2 \pm 0.1^{*}$ & 28.2 \\
\hline Male and female gamonts & $22 \pm 0.9$ & $11 \pm 0.3^{*}$ & 50 \\
\hline Developing oocysts & $30.2 \pm 1.2$ & $10.6 \pm 0.2^{*}$ & 64.7 \\
\hline Total number of parasitic stages & $66.4 \pm 2.8$ & $31.8 \pm 0.6^{*}$ & 52.1 \\
\hline
\end{tabular}

Number of various developmental stages are given per ten jejunal villi. All values are means \pm SD. * significance between infected group and infected-treated group.

expression of Bax and Caspase-3 (Figure 4). The SeNPs induced the downregulation of Bax and Caspase-3 gene expression. The Caspase-3 gene expression decreased significantly from 2.01 to 1.2 fold, and the Bax gene expression was downregulated from 2.9 to 2.3 fold after treatment with the SeNPs (Figure 4).

\section{DISCUSSION}

Nanoparticles are now offer new opportunities for noval medical treatments to counter infection by parasites (Alkhudhayri et al. 2018). For example, nano-selenium was used against schistosomiasis (Dkhil et al. 2016) and leishmaniasis (Beheshti et al. 2013).

This study demonstrated that SeNPs show anti-coccidial, antioxidant, and anti-apoptotic activities during E. papillata infection. The imbalance of the antioxidant defense system due to Eimeria infection leads to harmful cellular effects (Esch \& Petersen 2013). To control the oxidative stress induced by the infection, the parasite increases the levels of antioxidant enzymes such as CAT (Dkhil 2013). This enzyme catalyzes the conversion of hydrogen peroxide into water and oxygen. Thus, the level of $\mathrm{H}_{2} \mathrm{O}_{2}$ is diminished (Bosch et al. 2015). Additionally, the level of the biological marker malondialdehyde increases during infection with Eimeria (Dkhil et al. 2013). Treatment of the infected mice with SeNPs significantly reduced the oxidative damage caused by Eimeria infection. In our previous study, we proved that only the glutathione peroxidase activity increased in the jejuna of $E$. papillata-infected mice after treatment with NS (Alkhudhayri et al. 2018). 

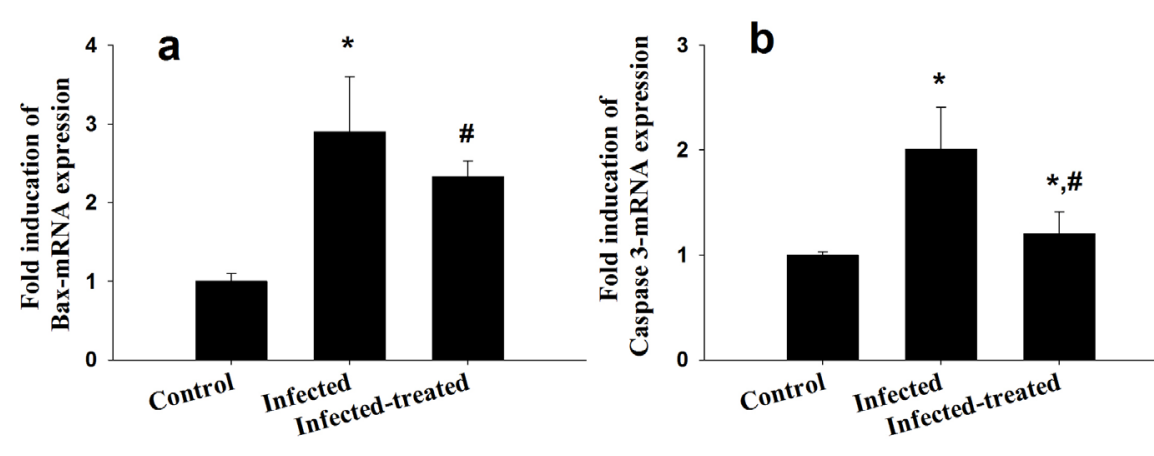

Figure 4. Effect of SeNPs on the mRNA expression of Bax (a) and Caspase 3 (b) in the jejunal samples from $E$. papillata-infected mice. The expression values obtained by RT-PCR analysis were normalized to the GAPDH mRNA level and are shown as fold induction (in $\log 2$ scale) relative to the mRNA level in the control. *: $p<$ 0.01 , significant change with respect to the control group; $\#: p<0.01$, significant change with respect to the infected group.

Table II. Effect of Selenium nanoparticles on the value of jejunal glutathione (GSH), malondialdehyde (MDA), nitric oxide (NO) catalase (CAT) and superoxide dismutase (SOD) of mice infected with E. Papillata.

\begin{tabular}{|c|c|c|c|c|c|}
\hline Group & $\begin{array}{c}\text { GSH } \\
(\mathbf{m g} / \mathbf{m g} \text { protein) }\end{array}$ & $\begin{array}{c}\text { MDA } \\
(\mathbf{n m o l} / \mathbf{m g} \text { protein) }\end{array}$ & $\begin{array}{c}\text { NO } \\
(\boldsymbol{\mu m o l} / \mathbf{m g} \text { protein) }\end{array}$ & $\begin{array}{c}\text { CAT } \\
(\mathbf{U} / \mathbf{m g})\end{array}$ & $\begin{array}{c}\text { SOD } \\
(\mathbf{U} / \mathbf{m g})\end{array}$ \\
\hline Control & $0.58 \pm 0.06$ & $70.46 \pm 6.70$ & $1.12 \pm 0.25$ & $61.04 \pm 7.61$ & $17.5 \pm 2.49$ \\
\hline Infected & $0.422 \pm 0.05^{\mathrm{a}}$ & $97.32 \pm 7.76^{\mathrm{a}}$ & $1.74 \pm 0.21^{\mathrm{a}}$ & $43.78 \pm 5.95^{\mathrm{a}}$ & $11.5 \pm 2.44^{\mathrm{a}}$ \\
\hline Infected-treated & $0.53 \pm 0.049^{\mathrm{b}}$ & $75.34 \pm 6.35^{\mathrm{b}}$ & $1.23 \pm 0.17^{\mathrm{b}}$ & $56.12 \pm 4.98^{\mathrm{ab}}$ & $17.02 \pm 3.22^{\mathrm{b}}$ \\
\hline
\end{tabular}

a indicates a significance against control group with $\mathrm{p}<0.001$. $\mathrm{b}$ indicates a significance against infected group with $\mathrm{p}<0.001$.

The oxidative damage induced in the jejuna of the infected mice activates molecular pathways to drive jejunal inflammation. Our previous study reported that NS could significantly improve the histopathological changes caused in the jejunum due to E. papillata infection, and also increase the glutathione peroxidase level in the jejunum of infected mice (Alkhudhayri et al. 2018).

In this study, we focused extensively on the oxidant/antioxidant status during Eimeria infection. The results showed that SeNPs work as excellent antioxidants. This was evidenced by the increase in lipid peroxidation, and the increase in SOD activity due to the enhanced scavenging of $\mathrm{O}_{2}$ after the treatment of the infected mice with the SeNPs.
The anti-eimerial effect of the SeNPs has been proven via two ways. The first way involves the decreased oocyst output in the feces from mice in the treated group. The second way involves the ability of the SeNPs to significantly $(p<0.01)$ decrease the number of meronts, gamonts, and developed oocysts in the jejuna from E. papillata-infected mice. Dkhil et al. (2013) proved the same effect, but by adding elemental selenium to the diet of the E. papillata-infected mice. Furthermore, Suradji et al. (2001) reported that selenium has a negative effect on the development of the pathogenic malarial parasite $P$. falciparum. Since the development of the parasite is affected by the intestinal microbiota, selenium could alter this effect (Hrdina et al. 2009, Kasaikina et al. 2012). 
In a variety of intracellular parasitic infections, apoptosis could regulate the host response to parasites and could help in the elimination of injured or infected cells (Lüder et al. 2001, Balamurugan et al. 2002). Tissue homeostasis is maintained by apoptosis (Vaux \& Strasser 1996), and the relationship between the developmental stages of E. papillata and host apoptosis has not yet been investigated intensively. In this study, the death of mouse jejunal cells was evidenced by a significant upregulation of the pro-apoptotic genes, Bax and caspase-3. Rossé et al. (1998) reported that Bax has been shown to induce cytochrome $c$ release and caspase activation, which in turn, leads to cell death. Our group reported the increase in the number of apoptotic cells in the jejuna from E. papillata-infected mice (Dkhil 2013, Metwaly et al. 2014). SeNPs could improve the eimeriosis-induced apoptotic changes in jejunal cells. The anti-apoptotic activity of SeNPs during myringosclerosis has also been documented by Görür et al. (2002).

Our results demonstrate that SeNPs possess an antioxidant and anti-apoptotic activity against murine eimeriosis. Further studies are required to elucidate the mechanism underlying their effects on the host and parasite.

\section{Acknowledgments}

This study was supported by Researchers Supporting Project (RSP-2019/23), Riyadh, King Saud University.

\section{REFERENCES}

ADAM H \& CAIHAK G. 1964. Grosses zoologisches parktikum tell. Arbeitsmethoden der makroskopischen und mikroskopischen anatomic. Mit 283 Abbildungen Gustav. Fischer Verlag: Stuttgart.

AEBI H. 1984. Catalase in vitro. In: Methods in Enzymology 105: 121-126.

ALKHUDHAYRI AA, DKHIL MA \& AL-QURAISHY S. 2018. Nanoselenium prevents eimeriosis-induced inflammation and regulates mucin gene expression in mice jejunum. Int J Nanomedicine 13: 1993-2003.

BAI K, HONG B, HE J, HONG Z \& TAN R. 2017. Preparation and antioxidant properties of selenium nanoparticlesloaded chitosan microspheres. Int J Nanomedicine 12: 4527-4539.

BALAMURUGAN K, RAJARAM R, RAMASAMI T \& NARAYANAN S. 2002. Chromium (III)-induced apoptosis of lymphocytes: death decision by ROS and Src-family tyrosine kinases. Free Radic Biol Med 33(2):1622-1640.

BEHESHTI N, SOFLAEI S, SHAKIBAIE M, YAZDI MH, GHAFFARIFAR F, DALIMI A \& SHAHVERDI AR. 2013. Efficacy of biogenic selenium nanoparticles against Leishmania major: in vitro and in vivo studies. J Trace Elem Med Biol 27(3): 203-207.

BERKELS R, PUROL-SCHNABEL S \& ROESEN R. 2004. Measurement of Nitric Oxide by Reconversion of Nitrate/ Nitrite to NO. In: Hassid A (Eds), Nitric Oxide Protocols. Methods Mol Biol 279: 1-8.

BLAKE D \& TOMLEY F. 2014. Securing poultry production from the ever-present Eimeria challenge. Trends Parasitol 30(1): 12-19.

BOSCH SS, KRONENBERGER T, MEISSNER KA, ZIMBRES FM, STEGEHAKE D, IZUI NM, SCHETTERT I, LIEBAU E \& WRENGER C. 2015. Oxidative stress control by apicomplexan parasites. Biomed Res Int 2015: 351289.

DKHIL M. 2013. Anti-coccidial, anthelmintic and antioxidant activities of pomegranate (Punica granatum) peel extract. Parasitol Res 112(7): 2639-2646.

DKHIL M, ABDEL-BAKI A, WUNDERLICH F, SIES H \& AL-QURAISHY S. 2013. Dietary selenium affects intestinal development of Eimeria papillata in mice. Parasitol Res 113(1): 267-274.

DKHIL M, AL-QURAISHY S, BAUOMY A \& DIAB M. 2016. Protective role of selenium nanoparticles against Schistosoma mansoni induced hepatic injury in mice. Biomed Res 27(1): 214-219.

ELLMAN GL. 1959. Tissue sulfhydryl groups. Arch Biochem Biophys 82(1): 70-77.

ESCH KJ \& PETERSEN CA. 2013. Transmission and epidemiology of zoonotic protozoal diseases of companion animals. Clin Microbiol Rev 26(1): 58-85.

GANGADOO S, DINEV I, CHAPMAN J, HUGHES RJ, VAN TTH, MOORE RJ \& STANLEY D. 2018. Selenium nanoparticles in poultry feed modify gut microbiota and increase abundance of Faecalibacterium prausnitzii. Appl Microbiol Biotechnol 102(3): 1455-1466. 
GEORGIEVA NV, KOINARSKI V \& GADJEVA V. 2006. Antioxidant status during the course of Eimeria tenella infection in broiler chickens. Vet J 172(3): 488-492.

GÖRÜR K, OZCAN C, POLAT A, UNAL M, TAMER L \& CINEL I. 2002. The anti-oxidant and anti-apoptotic activities of selenium in the prevention of myringosclerosis in rats. J Laryngol Otol 116(6): 426-429.

HRDINA J, BANNING A, KIPP A, LOH G, BLAUT M \& BRIGELIUSFLOHÉ R. 2009. The gastrointestinal microbiota affects the selenium status and selenoprotein expression in mice. J Nutr Biochem 20(8): 638-648.

HU C, LI Y, XIONG L, ZHANG H, SONG I \& XIA M. 2012. Comparative effects of nano elemental selenium and sodium selenite on selenium retention in broiler chickens. Anim Feed Sci Technol 177(3-4): 204-210.

JIANG J, OBERDÖRSTER G, ELDER A, GELEIN R, MERCER P \& BISWAS P. 2008. Does nanoparticle activity depend upon size and crystal phase? Nanotoxicology 2(1): 33-42.

KALISHWARALAL K, JEYABHARATHI S, SUNDAR K \& MUTHUKUMARAN A. 2014. A novel one-pot green synthesis of selenium nanoparticles and evaluation of its toxicity in zebrafish embryos. Artif Cells Nanomed Biotechnol 44(2): 471-477.

KASAIKINA MV, HATFIELD DL \& GLADYSHEV VN. 2012. Understanding selenoprotein function and regulation using rodent models. Biochim Biophys Acta 1823(9): 1633-1642.

KRÜCKEN J, DELIĆ D, PAUEN H, WOJTALLA A, EL-KHADRAGY M, DKHIL M, MOSSMANN H \& WUNDERLICH F. 2009. Augmented particle trapping and attenuated inflammation in the liver by protective vaccination against Plasmodium chabaudi malaria. Mal J 8(1): 54.

LAWAL J, JAJERE S, IBRAHIM U, GEIDAM Y, GULANI I, MUSA G \& IBEKWE BU. 2016. Prevalence of coccidiosis among village and exotic breed of chickens in Maiduguri, Nigeria. Vet World 9(6): 653-659.

LIVAK K \& SCHMITTGEN T. 2001. Analysis of Relative Gene Expression Data Using Real-Time Quantitative PCR and the 2- $\triangle \Delta C T$ Method. Methods 25(4): 402-408.

LÜDER CG, GROSS U \& LOPES MF. 2001. Intracellular protozoan parasites and apoptosis: diverse strategies to modulate parasite-host interactions. Trends Parasitol 17(10): 480-486.

MEHLHORN H. 2014. Encyclopedic Reference of Parasitology. $4^{\text {th }}$ ed., Berlin: Springer, p. 279-283.

METWALY M, DKHIL M \& AL-QURAISHY S. 2014. Anti-coccidial and anti-apoptotic activities of palm pollen grains on
Eimeria papillata-induced infection in mice. Biologia 69(2): 254-259.

NISHIKIMI M, APPAJI N \& YAGI K. 1972. The occurrence of superoxide anion in the reaction of reduced phenazine methosulfate and molecular oxygen. Biochem Biophys Res Commun 46(2): 849-854.

OHKAWA H, OHISHI N \& YAGI K. 1979. Assay for lipid peroxides in animal tissues by thiobarbituric acid reaction. Anal Biochem 95(2): 351-358.

OLA-FADUNSIN SD \& ADEMOLA IO. 2013. Anticoccidial effects of Morinda Lucida acetone extracts on broiler chickens naturally infected with Eimeria species. Pharm Biol 52(3): 330-334.

ROSSÉ T, OLIVIER R, MONNEY L, RAGER M, CONUS S, FELLAY I, JANSEN B \& BORNER C. 1998. BCl-2 prolongs cell survival after Bax-induced release of cytochrome c. Nature 391(6666): 496-499.

SCHITO M, BARTA J \& CHOBOTAR B. 1996. Comparison of Four Murine Eimeria Species in Immunocompetent and Immunodeficient Mice. J Parasitol 82(2): 255-262.

SURADJI EW, HATABU T, KOBAYASHI K, YAMAZAKI C, ABDULAH R, NAKAZAWA M, NAKAJIMA-SHIMADA J \& KOYAMA H. 2001. Selenium-induced apoptosis-like cell-death in Plasmodium falciparum. Parasitology 138(14): 1852-1862.

TSAKIRIS S, SCHULPIS KH, MARINOU K \& BEHRAKIS P. 2004. Protective effect of $L$-cysteine and glutathione on the modulated suckling rat brain $\mathrm{Na}+, \mathrm{K}+,-$ ATPase and $\mathrm{Mg} 2+-$ ATPase activities induced by the in vitro galactosaemia. Pharmacol Res 49(5): 475-479.

VAUX DL \& STRASSER A. 1996. The molecular biology of apoptosis. Proc Natl Acad Sci USA 93: 2239-2244.

\section{How to cite}

ALKHUDHAYRI A, AL-SHAEBI EM, QASEM MAA, MURSHED M, MARES MM, AL-QURAISHY S \& DKHIL MA. 2020. Antioxidant and anti-apoptotic effects of selenium nanoparticles against murine eimeriosis. An Acad Bras Cienc 92: e20191107. DOI. 10.1590/0001-3765202020191107.

Manuscript received on September 16, 2019, accepted for publication on October 14, 2019

\section{ABDULSALAM ALKHUDHAYRI ${ }^{1}$}

https://orcid.org/0000-0003-0972-9474

ESAM M. AL-SHAEBI ${ }^{1}$

https://orcid.org/0000-0003-1614-4802

MAHMOOD A.A. QASEM ${ }^{1}$

https://orcid.org/0000-0002-0939-6078 


\section{MUTEE MURSHED ${ }^{1}$}

https://orcid.org/0000-0003-3717-6424

\section{MOHAMMED M. MARES ${ }^{1}$}

https://orcid.org/0000-0002-0662-2113

\section{SALEH AL-QURAISHY}

https://orcid.org/0000-0003-4204-3124

MOHAMED A. DKHIL ${ }^{1,2}$

https://orcid.org/0000-0003-1869-5800

${ }^{1}$ Department of Zoology, College of Science, King

Saud University, Riyadh, Saudi Arabia

${ }^{2}$ Department of Zoology and Entomology, Faculty of Science,

Helwan University, 11795 Helwan, Ain Helwan, Cairo, Egypt

Correspondence to: Mohamed A. Dkhil

E-mail: mohameddkhil@yahoo.com

\section{Author contributions}

$A K, M A D$, and SA designed the study and critically revised the manuscript. AK, MAD, EMA, MAAQ, MM, SA and MMM contributed to the main experiment. All authors read and approved the final manuscript.

\section{(cc) BY}

